ББК 56.6

\title{
THE EFFECT OF SYNTHETIC AND NATURAL ANTIOXIDANTS ON THE EMERGENCE AND DEVELOPMENT OF MALIGNANT TUMORS
}

\author{
Erokhin Valeriy Nikolaevich \\ Senior Researcher, Department of Kinetics of Chemical and Biological Processes, \\ Institute of Biochemical Physics named after N.M. Emanuel of RAS \\ valery@sky.chph.ras.ru \\ Kosygina St., 4, 119334 Moscow, Russian Federation
}

\section{Krementsova Anna Vladimirovna}

Researcher, Department of Kinetics of Chemical and Biological Processes, Institute of Biochemical Physics named after N.M. Emanuel of RAS

valery@sky.chph.ras.ru

Kosygina St., 4, 119334 Moscow, Russian Federation

\section{Semenov Vladimir Alekseevich}

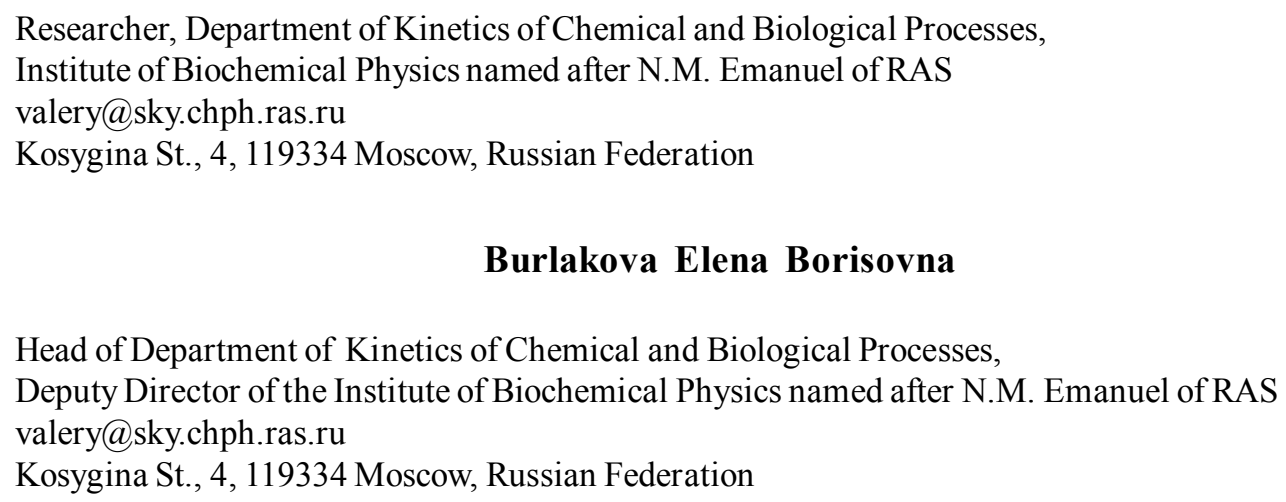

\section{Burlakova Elena Borisovna}

Head of Department of Kinetics of Chemical and Biological Processes, Deputy Director of the Institute of Biochemical Physics named after N.M. Emanuel of RAS valery@sky.chph.ras.ru

Kosygina St., 4, 119334 Moscow, Russian Federation

Abstract. The effect of different doses of synthetic antioxidant $\beta$-(4-hydroxy3,5-ditertbutylphenyl), propionic acid (phenosan) and savory essential oil on the development of spontaneous leukemia was studied. The drug efficiency was determined from the survival curves, animal life spans, and the incidence of leukemia. Phenosan is characterized by clear antitumor activity in therapeutic $\left(10^{-4} \mathrm{~mol} / \mathrm{kg}\right)$ and ultra-low $\left(10^{-14} \mathrm{~mol} / \mathrm{kg}\right)$ doses. The dose of $10^{-14} \mathrm{~mol} / \mathrm{kg}$ increases the life span. The savory essential oil in low doses mixed with drinking water $(150 \mathrm{ng} / \mathrm{ml})$ or food $(2,5 \mu \mathrm{g} / \mathrm{g})$ increased the average lifetime of mice by $20-35 \%$. The low doses of these drugs seem promising as preventive drugs.

Key words: antioxidants, low doses, propionic acid, spontaneous leukemia, preventive drugs. 


\section{Introduction}

One of the main consequences of exposure to harmful ecological factors (radiation, carcinogens, etc.) is high risk of malignant diseases.

The problem of malignant diseases prevention and the search for drugs decelerating or arresting the development of malignant neoplasms is very urgent. We used $\beta$-(4-hydroxy3,5-ditertbutylphenyl) propionic acid (phenosan), an antioxidant of the hindered phenols class, as a possible prophylactic. This antioxidant was synthesized at the Emanuel Institute of Biochemical Physics of the Russian Academy of Sciences (Moscow).

It is known that many products of plant origin, i.e. herbs, spices, and their extracts, possess wide biological activity, including antioxidant and pharmacological properties [7, 12]. These compounds are applied in small doses; they have low toxicity and are recommended for use to decrease the risk of disease caused by increased oxidation of cell components.

Among natural antioxidants of plant origin, the important place is taken by essential oils which are a mixture of volatile compounds isolated from spice aromatic plants. The presence of antioxidant properties in many essential oils, including ones that do not contain phenol derivatives, has been proved in model experiments [13].

Savory essential oil used in the work contained $0.5-1.7 \%$ of each of the following monoterpene carbohydrates ( $\alpha$-thujene, $\alpha$-pinene, camphene, $\beta$-pinene, $\beta$-myrcene, sabinene, $\alpha$ phellandrene, $\alpha$-terpinene), $2.1 \%$ of $\gamma$-cymene, $14.8 \%$ of $\gamma$-terpinene, $2.8 \%$ of bornyl acetate, $18.1 \%$ of thymol, $37.8 \%$ of carvacrol, and $4 \%$ of caryofillen. A high content of thymol, carvacrol, and $\gamma$-terpinene was responded for the antioxidant activity of the oil $[13,15]$. It was revealed earlier that the addition of thyme oil (1200 mg per $1 \mathrm{~kg}$ of mass) to rats feed increased the general antioxidant status of the animals and kept a high level of polyunsaturated fatty acids in cell membranes during the process of their aging [16].

Our research line agrees with the current trend in cancer prevention by efficient low toxicity compounds including antioxidants [6]. Many drugs in low and ultra-low doses demonstrate activities comparable to those in therapeutic doses [4], while their toxicity is much lower.
The goal of this work was to study the effect of phenosan and the essential oil summer savory (Satureja hortensis L.) in low and ultra-low doses on the life span and development of spontaneous leukemia in AKR mice.

The model of AKR mice is interesting since spontaneous leukemia is observed in $65-95 \%$ of these mice at the age of $6-11$ months [2]. Note that mouse spontaneous leukemia is most close to human leukemia by the origin, clinical presentation, and morphological properties [1, 11]. Previously, we carried out a detailed kinetic study of the development of different leukemia forms in AKR mice (Erokhin and Burlakova, 2003) [9]. The kinetic curves of hematological indices (leukocyte count, count of blood corpuscles that can increase the number of leukocytes, and count of undifferentiated (leukemia) cells)) were plotted and NMR spectra were obtained for lymphocytes, which allows to distinguish cells at different stages of differentiation.

\section{Materials and methods}

Experiments were carried out on AKR mice at the age of 3-4 months. Phenosan was administered in four doses of $10^{-4}$ and $10^{-14} \mathrm{~mol} / \mathrm{kg}$ in saline $(0.2 \mathrm{ml} /$ mouse $)$ with an interval of one day.

In savory experiments mice of the first experimental group got drinking water, in which the essential oil of summer savory Satureja hortensis L. (Lionel Hitchen Ltd., Great Britain) was added, and standard laboratory feed ad libitum. The content of the essential oil in drinking water was $0.15 \mathrm{mg}$. This water was placed into waterers in a sufficient amount. Mice of the second experimental group got pure drinking water and food, into which the essential oil was added. For obtaining this feed, $0.5 \mathrm{~g}$ of savory essential oil was mixed with $100 \mathrm{~g}$ of glucose; $50 \mathrm{~g}$ of this mixture was added to $100 \mathrm{~g}$ of feed and mixed until equal distribution. Consequently, $1 \mathrm{~g}$ of feed contained about $2.5 \mu \mathrm{g}$ of savory essential oil.

The experiment was performed for 17 months until the natural death of the last animal.

The life span was recorded from the available dates of animal birth and death. The weight of organs replaces with leukemia cells, thymus and spleen, was determined within one day after death. Leukemia was determined within one day after death. Leukemia was identified in dead animals by increased weight of thymus (more than $50 \mathrm{mg}$ ) and spleen (more than $200 \mathrm{mg}$ ). 
The development of leukemia was evaluated according to the life span of affected animals. The leukemia incidence in controlled animals and animals administered with drugs is studied.

The survival (proportion of survived animals vs. age) curves were plotted from the life span data. In order to quantify the drug impact on the leukemia, the Gompertz function was used for nonlinear approximation of the survival curves [10]:

$$
S(t)=e\left(-\frac{h_{0}}{\gamma}\left(e^{\gamma t}-1\right)\right)
$$

where $S(t)$ is the proportion of animals that survived to age $t$; and $h_{0}$ and $\gamma$ are parameters of the function. The process rate largely depends on the value. These parameters were calculated using the Gauss - Newton least squares method.

The rate of leukemia development and the drug efficiency were quantified from the modal age $\tau_{\text {mod }}$ when the survival curve had the maximum slope (inflection point) and the population death rate reaches the maximum (mode):

$$
\tau_{\text {mod }}=\frac{\ln \gamma-\ln \left(h_{0}\right)}{\gamma}
$$

The difference between these values in experiment and control describes the efficiency of the impact:

$$
\Delta \tau_{\bmod }=\tau_{\bmod }^{\exp }-\tau_{\bmod }^{\text {contr }}
$$

In addition to these parameters, the Gompertz function was used to calculate the mean life $\operatorname{span} \tilde{\tau}$ :

$$
\widetilde{\tau}=\frac{\ln \gamma-\ln \left(h_{0}\right)-C_{0}}{\gamma}
$$

where $C_{0}=0.577$ is the Euler constant.

\section{Results and discussion}

In order to analyze the obtained data, the survival curve was divided into four conventional parts (quantiles) corresponding to different age subpopulations; in particular, the first and fourth quantiles corresponded to the short-lived and longlived subpopulations, respectively. This approach allowed us to reveal the patterns of the effect of different modes of phenosan administration on different age subpopulations in AKR mice.

Figure 1 and Table 1 presents the data on the impact of phenosan dose of $10^{-4} \mathrm{~mol} / \mathrm{kg}$ on leukemia development in AKR mice. The presented control and experimental survival curves significantly differ according to the Kolmogorov-Smirnov test $(p<0.05)$. In addition, increased mean life span (by 37 days) and modal age $\left(\Delta \tau_{\text {mod }}=29.9\right.$ days $)$ were observed.

A significant $(p<0.05)$ effect of a single administration of $10^{-4} \mathrm{~mol} / \mathrm{kg}$ phenosan was observed (the mean life span increased by 25.2 days).

At the same time, administration of four substantially lower doses $\left(10^{-14} \mathrm{~mol} / \mathrm{kg}\right)$ also had significant anticancer effect (Fig. 2, Table 1). Under these conditions, phenosan not only increased the mean life span by more than 40 days but also decreased the leukemia incidence and increased the maximum life span by 61 days.

This indicates that this phenosan dose had the greatest impact on the long-lived subpopulation. The modal age increased by 39.6 days, which points to a decreased rate of leukemia development. The survival curves of mice administered saline did not significantly differ from the control curves (intact animals) according to the Kolmogorov-Smirnov test (Fig.1, curve 2).

It is common knowledge that the mean life span can considerably vary from cohort to cohort even in genetically similar animals [5]. We also observed this pattern. The maximum life span in AKR mice is about 350 days (Figs. 1, 2) [9].

However, one of preliminary experiments demonstrated an abnormally short life span in control (the maximum life span was 275 days). In this particular experiment, phenosan at the dose of $10^{-14} \mathrm{~mol} / \mathrm{kg}$ considerably increased the maximum life span (almost 1.5-fold; Fig. 3).

The obtained result complies with the published data: the efficiency of antioxidants substantially depends on the body state $[3 ; 8$; 14]. Antioxidants have little effect on the life span of "viable" individuals (with a relatively high life span).

The kinetic parameters of these curves are presented in the table 2 , which shows that the value of the parameter, determining the latent period, in the experiment is lower than in the control. 


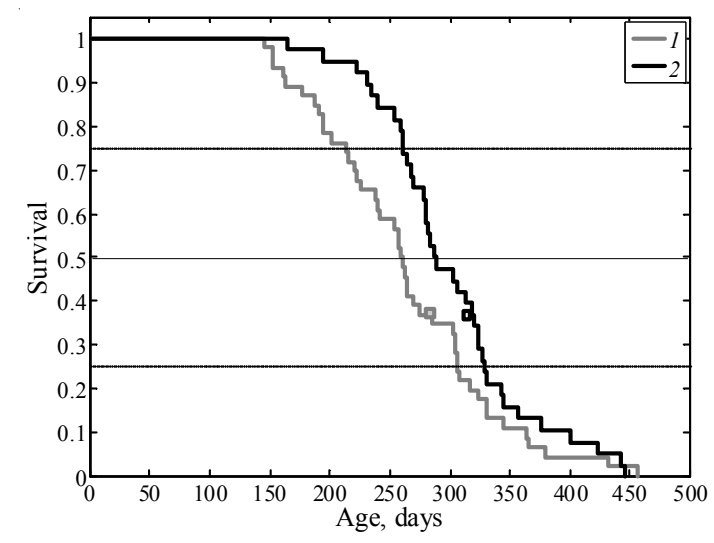

Fig. 1. Survival curves of leukemic AKR mice in control (1) and after administration of four phenosan doses of $10^{-4} \mathrm{~mol} / \mathrm{kg}(2)$; squares indicate the modal age

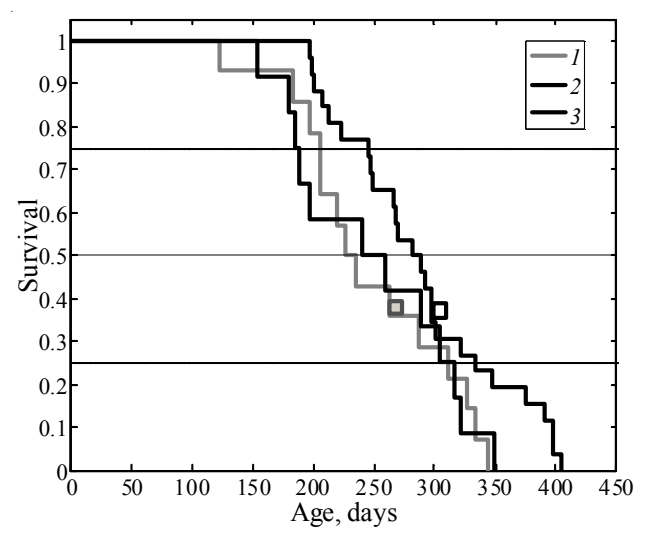

Fig. 2. Survival curves of leukemic AKR mice in control (1),

after administration of saline (2), and after administration of four phenosan doses of $10^{-14} \mathrm{~mol} / \mathrm{kg} \mathrm{(2)}$; squares indicate the modal age

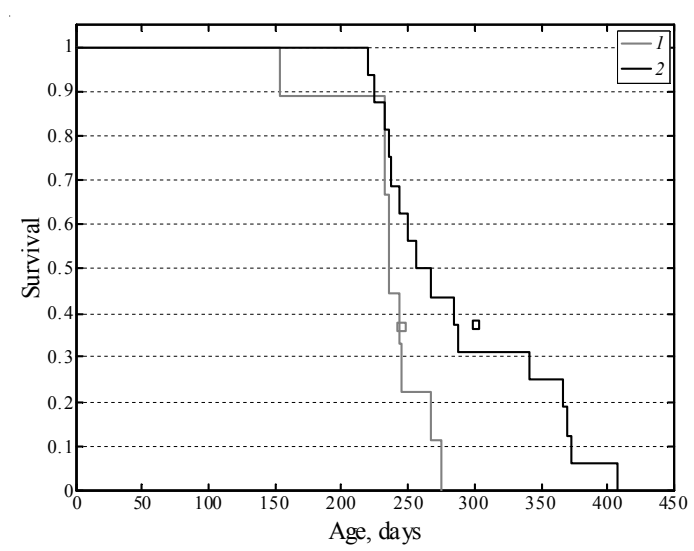

Fig. 3. Survival curves of leukemic AKR mice in control (1) and after administration of four phenosan doses of $10^{-14} \mathrm{~mol} / \mathrm{kg}(2)$; squares indicate the modal age 
Parameters of spontaneous leukemia development in AKR mice in control and after administration of four phenosan doses of $10^{-4}$ and $10^{-14} \mathrm{~mol} / \mathrm{kg}$

\begin{tabular}{|c|c|c|}
\hline Parameter & Control & Phenosan \\
\hline \multicolumn{3}{|c|}{$10^{-4} \mathrm{~mol} / \mathrm{kg}$ (four injection) } \\
\hline$h_{0}$ & $\begin{array}{c}1.870 \times 10-{ }^{4} \\
95 \% \text { confidence } \\
\text { interval } \\
{[1.472-2.270] \times 10^{-4}}\end{array}$ & $\begin{array}{c}2.720 \times 10-^{5} \\
95 \% \text { confidence interval } \\
{[1.522-3.918] \times 10^{-5}}\end{array}$ \\
\hline$\gamma$ & $\begin{array}{c}0.0156 \\
95 \% \text { confidence } \\
\text { interval } \\
{[0.0146-0.0166]}\end{array}$ & $\begin{array}{c}0.0212, \\
95 \% \text { confidence interval } \\
{[0.0195-0.0229]}\end{array}$ \\
\hline Modal age, days & 284.0 & 313.9 \\
\hline$\tau_{\text {mod }}^{\text {exp }}-\tau_{\text {mod }}^{\text {contr }}$ & \multicolumn{2}{|c|}{29.9} \\
\hline Mean lifespan, days & 263.6 & 300.6 \\
\hline Maximum lifespan, day & 456 & 446 \\
\hline Leukemia incidence, $\%$ & 93.9 & 92.7 \\
\hline \multicolumn{3}{|c|}{$10^{-14} \mathrm{~mol} / \mathrm{kg}$ (four injection) } \\
\hline$h_{0}$ & $\begin{array}{c}3.1727 \times 10^{-4} \\
95 \% \text { confidence } \\
\text { interval } \\
{[1.210-5.135] \times 10^{-4}}\end{array}$ & $\begin{array}{c}1.0671 \times 10^{-4}, \\
95 \% \text { confidence interval } \\
{[0.0481-0.1653] \times 10^{-4}}\end{array}$ \\
\hline$\gamma$ & $\begin{array}{c}0.0144 \\
95 \% \text { confidence } \\
\text { interval } \\
{[0.0112-0.0176]}\end{array}$ & $\begin{array}{c}0.0165, \\
95 \% \text { confidence interval } \\
{[0.0142-0.0189]}\end{array}$ \\
\hline Modal age, days & 265.2 & 304.8 \\
\hline$\tau_{\text {mod }}^{\exp }-\tau_{\text {mod }}^{\text {contr }}$ & \multicolumn{2}{|c|}{39.6} \\
\hline Mean lifespan, days & 247.1 & 288.9 \\
\hline Maximum lifespan, day & 344 & 405 \\
\hline Leukemia incidence, $\%$ & 88.2 & 78.8 \\
\hline
\end{tabular}

The parameters of the course of spontaneous leukosis

in the AKR line of mice in the control and in the case of consumption of savory essential oil with drinking water and food

\begin{tabular}{|l|c|c|}
\hline Index & Control & Savory \\
\hline \multicolumn{2}{|c|}{ Consumption with water in a dose of $1.5 \mu \mathrm{g} /$ day } \\
\hline$h_{0}$ & $1.783 \times 10^{-4}$ & $2.369 \times 10^{-5}$ \\
\hline$\gamma$ & 0.0176 & 0.0214 \\
\hline Average lifetime & $254 \pm 9$ & $301 \pm 8$ \\
\hline \multicolumn{2}{|c|}{ Consumption with food in a dose of $50 \mu \mathrm{g} /$ day } \\
\hline$h_{0}$ & $1.052 \times 10^{-4}$ & $2.962 \times 10^{-5}$ \\
\hline$\gamma$ & 0.0209 & 0.0203 \\
\hline Average lifetime & $250 \pm 20$ & $325 \pm 17$ \\
\hline
\end{tabular}




\section{ТЕХНИКО-ТЕХНОЛОГИЧЕСКИЕ ИННОВАЦИИ}

Figure $4 \mathrm{a}$ represents the survival curves of the AKR line of mice in the control and in the case of administration of savory essential oil with drinking water, and Fig.5 represents the analogous data for the case of administration of the essential oil with feed. It is seen that the essential oil in both methods of administration shows remarkable antileukemic action: the survival curves of experimental groups of mice are significantly shifted to the right in comparison with the control. The difference in the date of the beginning of animal mortality is marked in both cases: in the control grope it began after 120 days, in the experimental groups it began after 200-250 days. Figure $4 \mathrm{~b}$ shows the curves of death rate of the animals. It is obvious that the initial level of mortality in the control group is higher than in the group obtaining savory essential oil. All the survival curves were fitted by the Gompertz function.

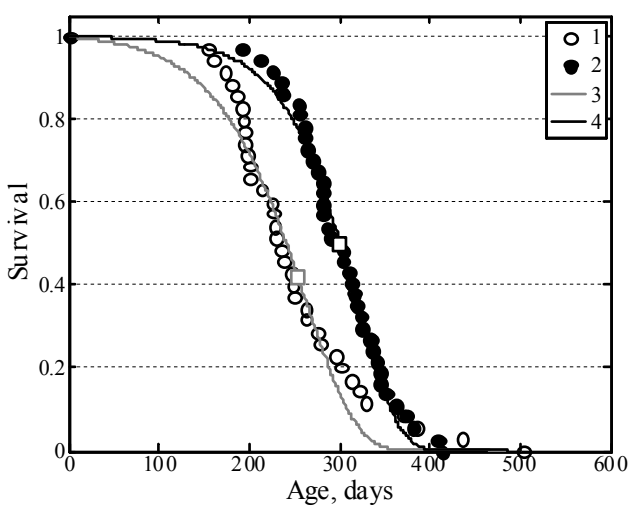

$a$

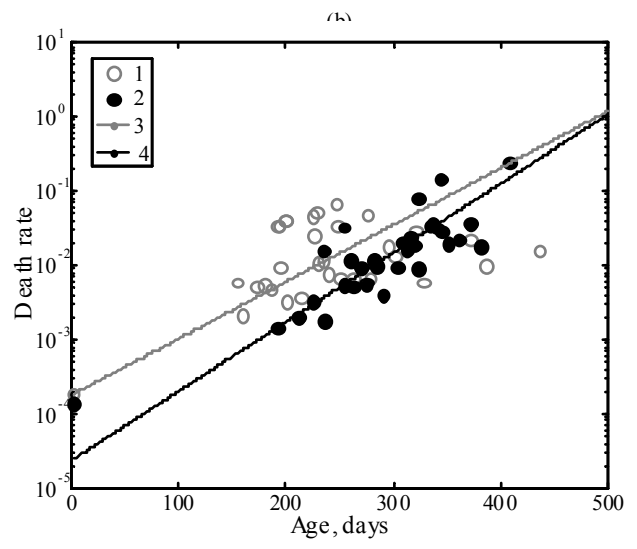

$b$

Fig. 4. Survival curves of AKR line mice (a) in the control (1) and in the case of addition of savory oil into drinking water (2).

Approximate Gompertz function in the control (3) and in the experiment (4).

Selected values of the average lifespan are marked by squares.

Death rate of AKR line mice (b) in the control (1) and in the case of addition of savory oil into drinking water (2)

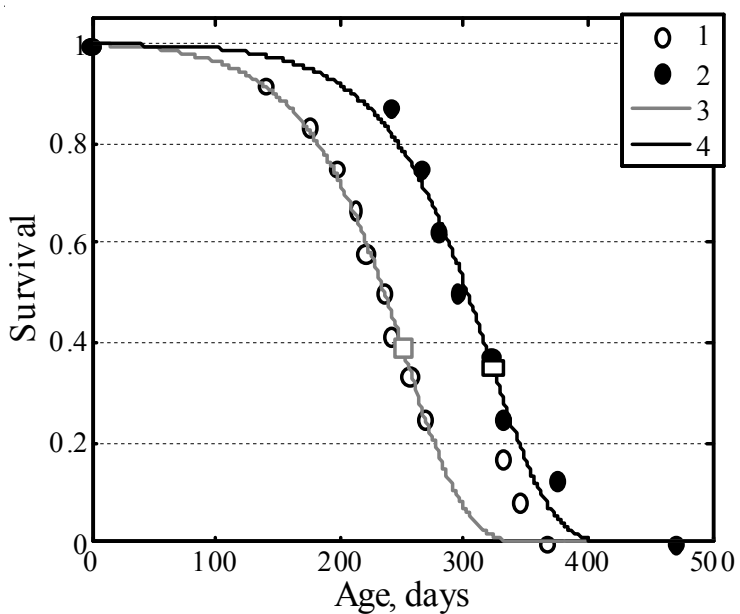

Fig. 5. Survival curves of AKR line mice in the control (1) and in the case of addition of savory oil to feed (2). Approximate Gompertz function in the control (3) and in the experiment (4).

Selected values of the average lifespan are marked by squares 


\section{Conclusion}

The obtained results allow us to conclude that the use of synthetic and natural antioxidants in small doses is promising for treatment and prophylactic aims.

The authors thank T.A. Misharina for the provision of essential savory oil for research.

\section{REFERENCES}

1. Bergolts V.M., Rumyantsev N.V. Comparative Pathology and Etiology of Human and Animals. Moscow, Meditsina Publ., 1966 (in Russian).

2. Blandova Z.K., Dushkin V.A., Malashenko A.M., et al. Laboratory Strains of Mice for MedicalBiological Investigations. Moscow, Nauka Publ., 1983 (in Russian).

3. Burlakova E.B., Alesenko A.V, Molochkina E.M., et al. Bioantioxidants in Radiation Injury and Malignant Growth. Moscow, Nauka Publ., 1975 (in Russian).

4. Burlakova E.B. Effect of Ultra-Low Doses. Herald of Russian Academy of Sciences, 1994, vol. 64, no. 5, pp. 425-431 (in Russian).

5. Carnes B.A., Olshansky S.J., Heterogeneity and Its Biodemographic Implications for Longivity and Mortality. Experim. Gerontol, 2001, vol. 36, pp. 419-430.

6. Chung W.-Y., Jung, Y.-J., Surh, Y.-J., et al. Antioxidative and Antitumor Promoting Effects of [6]Paradol and Its Homologs. Mutat. Res., 2001, vol. 496, pp. 199-206.

7. Dragland S., Senoo H., Wake K., et al. Several Culinary and Medicinal Herbs Are Important Sources of Dietary Antioxidants. J. Nutr., 2003, vol. 133, pp. 1286-1290.

8. Driver C., Georgeous A. Variable Affects of Vitamin E on Drosophila Longevity. Biogerontology, 2003, vol. 4, no. 2, pp. 91-95.

9. Erokhin V.N., Burlakova E.B. Spontaneous Leukemia - a Model for Studying the Effects of Low and Ultralow Doses of Physical and Physicochemical Factors on Tumorigenesis. Radiats. Biol. Radioekol., 2003, vol. 43, no. 2, pp. 237-241.

10. Gompertz B. On the Nature of the Expressive Function of the Law of Human Mortality and on a New Mode Determining Life Contingencies. Philosoph. Trans. Royal Soc. London, Ser. A, 1825, vol. 115, pp. 513-585.

11. Kassirskii I.A. Introduction to Clinical Hematology. Moscow, Meditsina Publ., 1964.

12. Lampe J.W. Spicing up a Vegetarian Diet: Chemopreventive Effects of Phytochemicals. Am. J. Clin. Nutr., 2003, vol. 78, pp. 579-583.

13. Misharina T.A., Terenina M.B., Krikunova N.I. Antioxidant Properties of Essential Oils. Prikl. Biokhim. Mikrobiol., 2009, vol. 45, no. 6, pp. 642-647. (in Russian)

14. Orr W.C., Sohal R.S., Does Overexpression of $\mathrm{Cu}, \mathrm{Zn}$-SOD Extend Life Span in Drosophila Melanogaster? Exp. Gerontol., 2003, vol. 38, pp. 227-230.

15. Ruberto G., Baratta M. Antioxidant Activity of Selected Essential Oil Components in Two Lipid Model Systems. Food Chem., 2002, vol. 69, no. 1, pp. 167-174.

16. Youdim K.A., Deans S.G. Effect of Thyme Oil and Thymol Dietary Supplementation on the Antioxidant Status and Fatty Acid Composition of the Ageing Rat Brain. British J. Nutr, 2000, vol. 83, pp. 87-93.

\section{ВЛИЯНИЕ СИНТЕТИЧЕСКИХ И ПРИРОДНЫХ АНТИОКСИДАНТОВ НА ВОЗНИКНОВЕНИЕ И РАЗВИТИЕ ЗЛОКАЧЕСТВЕННЫХ ОПУХОЛЕЙ}

\section{Ерохин Валерий Николаевич}

Старший научный сотрудник, отдел кинетики химических и биологических процессов, Институт биохимической физики им. Н.М.Эмануэля РАН valery@sky.chph.ras.ru ул. Косыгина, 4,119334 г. Москва, Российская Федерация

\section{Кременцова Анна Владимировна}

Научный сотрудник, отдел кинетики химических и биологических процессов, Институт биохимической физики им. Н.М.Эмануэля РАН valery@sky.chph.ras.ru ул. Косыгина, 4,119334 г. Москва, Российская Федерация 


\section{ТЕХНИКО-ТЕХНОЛОГИЧЕСКИЕ ИННОВАЦИИ}

\section{Семенов Владимир Алексеевич}

Научный сотрудник,

отдел кинетики химических и биологических процессов, Институт биохимической физики им. Н.М. Эмануэля РАН valery@sky.chph.ras.ru ул. Косыгина, 4,119334 г. Москва, Российская Федерация

\section{Бурлакова Елена Борисовна}

Заведующая отделом кинетики химических и биологических процессов, заместитель директора Института биохимической физики им. Н.М.Эмануэля РАН valery@sky.chph.ras.ru ул. Косыгина, 4,119334 г. Москва, Российская Федерация

Аннотация. В работе исследовано влияние различных доз синтетического антиоксиданта - $\beta$ (4-гидрокси-3,5-ди-трет-бутилфенил), пропионовой кислоты (фенозан) и эфирного масло чабер на развитие спонтанного лейкоза. Эффективность препарата определяли согласно данным кривых выживания и продолжительности жизни животных, а также показателям заболеваемости лейкозом. Фенозан характеризуется явной противоопухолевой активностью при приеме в терапевтических $\left(10^{-4}\right.$ мол/кг) и минимальных (10-14 мол/кг) дозах. Доза $10^{-14}$ мол/кг увеличивает продолжительность жизни. Показано, что применение малых доз этих препаратов может быть перспективным в качестве профилактического средства.

Ключевые слова: антиоксиданты, малые дозы, пропионовая кислота, спонтанный лейкоз, профилактические средства. 